Article

\title{
Sharing Economy and Lifestyle Changes, as Exemplified by the Tourism Market
}

\author{
Agnieszka Niezgoda and Klaudyna Kowalska *(D) \\ Department of International Economics, Institute of International Business and Economics, \\ Poznań University of Economics and Business, Al. Niepodległości 10, 61-875 Poznań, Poland; \\ agnieszka.niezgoda@ue.poznan.pl \\ * Correspondence: klaudyna.kowalska@ue.poznan.pl
}

Received: 30 April 2020; Accepted: 29 June 2020; Published: 2 July 2020

check for updates

\begin{abstract}
The aim of the article is to analyze the relationship between lifestyle changes and willingness to use sharing economy services in tourism, including peer-to-peer accommodation. On the one hand, knowledge of lifestyle changes can help adapt the product offer to the requirements of consumers. On the other hand, products that consumers use can reflect lifestyle changes. The following classification of motivations for sharing economy activity selection resulting from the subjects' lifestyles has been proposed: personal motivations-related to economic advantages; social (conformist) motivations - resulting from the need to fit in with others; and ideological motivation-resulting from the understanding of the processes of natural environment degradation and excessive consumption. In order to gather opinions and to understand behaviors, attitudes, and preferences regarding sharing economy activities (i.e., the sharing of transportation, food, clothes, equipment, and accommodation), the focus group interview method was used (6 groups, 5-8 participants each). Discussions were conducted separately for two populations: young with time (YT) and older rich (OR). The study demonstrates lifestyle changes between the generations. YT actions are the consequence of personal and ideological motivations. OR have lifestyles that result from personal and conformist motivations. Neither population sees a relationship between participating in the sharing economy and caring for the environment and preventing excessive consumption.
\end{abstract}

Keywords: consumer behavior; lifestyle; sharing economy; peer-to-peer accommodation; tourism market

\section{Introduction}

The growing importance of the sharing economy is a consequence of many simultaneous changes: the global economic crisis, growing concerns about sustainable consumption, the development of information and communication technologies (ICTs), a tendency towards reurbanization, changes in consumers' behaviors, and increasingly widespread initiatives related to social entrepreneurship [1-5]. Despite the lack of empirical evidence, the rise of the sharing economy and the 2008 financial crisis are often linked [5,6]. As a result of the crisis, discussions of sustainable development, including sustainable consumption, have intensified. In recent years, interest in the sharing economy has increased. The new economic situation has led to a reassessment of consumption patterns, including spending habits and the value attached to ownership [6-8], thus making it necessary to rethink the changes in previously existing behaviors resulting from one's lifestyle. The sharing economy has provided useful business models for consumers who engage in anti-consumption lifestyles, because a number of consumers see participation in the sharing economy as an alternative to ownership [9] (pp. 1422-1423). 
Lifestyle is considered by many authors as one of the factors in consumer behavior [10-13]. In the tourist market, lifestyle can affect tourists' behaviors and determine the choices they make regarding, e.g., how they travel and what services they use [14-17]. It is natural for people to constantly pursue a higher standard of living [18]. This pursuit can be manifested by the wish to constantly improve one's economic standing, but may involve non-financial aspects of life as well. Consumers create tendencies and are incredibly demanding about what they want and do not want. Tourists as consumers seek products that can adapt to their lifestyle [13]. Knowledge of lifestyle changes can help adapt the product offer to the requirements of consumers. At the same time, products that consumers use can reflect lifestyle changes. The idea of sharing is important, mainly in the context of satisfying unlimited needs under conditions of limited resources. The sharing economy is seen as a way to reach sustainability [19] (p. 19). It may be considered a sustainable business model [20] that will change consumers' relationship to objects and other components of a materialistic lifestyle [5]. Consumers are increasingly aware of environmental, economic, and social issues. Their growing concern for the environment may lead to more rational purchasing decisions [21,22] and prompt them to search for providers with a sustainable business model. Consumers' lifestyles and values are changing, and consumer behavior patterns are changing with them $[13,21,23]$. This also applies to leisure time and the ways it is managed, including the choice of accommodation during travel $[16,23,24]$. Changes in lifestyle could reduce the excessive consumption of goods, and promote more responsible consumer behaviors [5] and more sustainable business models.

The objective of the article is to analyze the relationship between lifestyle changes and readiness to use peer-to-peer accommodation services, which are part of the sharing economy. In order to achieve this objective, it was first necessary to analyze this relationship in a broader context, by assessing consumers' sense of responsibility for the use of resources, and their engagement in sharing economy activities, involving the sharing of transportation, food, clothes, and equipment. The key issue for the study was the focus on the behavioral aspect of respondents' attitudes. Once the respondents' general attitude towards the sharing economy was known, it was possible to examine their hidden motives resulting from lifestyle changes in the context of travel patterns and accommodation. Therefore, as well as respondents' declarations of whether they performed certain actions, their motivations behind choosing (or not choosing) peer-to-peer accommodation and other sharing economy activities was examined. The paper is based on the authors' own classification of motivations (personal, social, and ideological), with an attempt to verify these motivations based on qualitative research in six focus groups.

The systematic literature review in the article contributes to a clearer understanding of lifestyle changes in the context of the sharing economy. The review was carried out with a view to identifying existing research directions in this field. While an abundant literature covers tourists' motivations for participating in the sharing economy [1,2,23-29], researchers have paid less attention to these tourists' lifestyles [28], and more importantly, to how lifestyle influences their behavior in the context of the sharing economy. This paper contributes to a better understanding of the lifestyle changes associated with behaviors, attitudes, and preferences regarding sharing economy initiatives. In addition, the qualitative study enabled a thorough analysis of hidden motives resulting from the subjects' lifestyle and the gap between lifestyle changes and the use of peer-to-peer accommodation, which, to the best of the authors' knowledge, has not been covered in any previous research. The study reveals differences between generations in terms of: (1) lifestyle and a sense of responsibility for the use of resources; (2) lifestyle and motivations for participating in sharing economy activities, including the sharing of transportation, food, clothes, and equipment; (3) lifestyle and motivations for the specific organization of travel and use of peer-to-peer accommodation. The focus group study offers a better understanding of the role of lifestyle changes in the sharing economy and the popularization of sustainable business models. The results contribute to the literature on peer-to-peer services by including a lifestyle perspective, allow the establishment of an informational background, offer a 
starting point for further quantitative research in this field, and provide some guidelines for tourism companies with sustainable business models.

\section{Systematic Literature Review—Lifestyle, Sharing Economy and Peer-to-Peer Accommodation}

Lifestyle is a term which is often used in conjunction (or sometimes even replaced) with terms such as "the way, quality and standard of living", "patterns of behavior", "values", and "attitudes". In the literature, one can find various attempts to define this term, as it falls within the scope of interest of scholars from the fields of economics, psychology, sociology, pedagogy, and medicine [10]. As a result, there is no single commonly accepted definition of lifestyle.

Lifestyle includes observable behaviors and non-observable values [10,30]. According to scholars, lifestyle is a method of market segmentation; they have emphasized, however, that it has never been accepted as the dominant method [14]. Lifestyle is intrinsically associated with psychographic methods of market segmentation. In literature, there have been many attempts to determine the lifestyle characteristic for societies in developed countries, so as to make it easier to profile market segments, develop the concept of market position, develop advertisements, etc. Lifestyle comprises behaviors, knowledge, and attitudes-both what people do and what they feel. It is a complex and evolving category, which can include both differences and similarities, due to the multi-directional transmission of cultural values [31]. Although it is hard to find a single, all-encompassing definition of lifestyle, the fact that lifestyle in developed countries undergoes transformations is commonly accepted in literature [13].

From the perspective of this article, it is worth considering whether analyses of lifestyle refer to attitudes and values opposing consumption, and to the sharing economy. Tourism is associated with the way people spend their time and with personal preferences; therefore, one might assume that choices people make concerning tourist services can be the consequence of a specific lifestyle.

\subsection{Lifestyle Changes and the Sharing Economy}

Educational campaigns for rational and healthy living contribute to the rationalization of some areas of consumption [32], including the way people satisfy their need to relax, as well as other needs that involve tourist activities. Excessive mass consumption is increasingly rejected in favor of sustainable consumption and de-consumption, i.e., the conscious limitation of consumption to a rational size [4,33-35], which can be observed especially in groups of young, educated individuals who use digital media and technology $[3,36]$. Furthermore, consumers are becoming more rational, responsible, and aware when it comes to issues related to environment protection [37] and are aiming at sustainable consumption. On the other hand, consumers are exposed to constant pressure related to the artificial stimulation of certain needs, mainly through aggressive advertising, which leads to the so-called Diderot effect, whereby people pursue their ideal of a good life through the purchase of particular consumer goods, purchasing more than one actually needs [38]. Thus, consumers' behavior is becoming clearly inconsistent-they aim at limiting consumption, but at the same time they buy more, because they want to satisfy all their needs [3]. The concept of the sharing economy can be seen as an attempt to reconcile the two perspectives (i.e., simultaneously using products and limiting purchases). 
The sharing economy — which is essentially about better management of underused assets-has become one of the leading economic trends in the 2010s. It is an economic and technological idea that can be perceived as an umbrella term for changes occurring within modern technologies and including collaborative consumption [39]. Collaborative consumption endorses sharing the consumption of goods and services through online platforms [39] and can include the following activities: traditional sharing, bartering, lending, trading, renting, gifting, and swapping, providing benefits related to accessing products and services rather than owning them [7,39-41].

The growth of the sharing economy in tourism, driven by the global economic crisis, the development of modern technologies, environmental factors (de-consumption, sustainable consumption), and the increased significance of authenticity and sense of community $[1-3,7,16,42-44]$ has led to the emergence of many businesses that enable and coordinate the direct exchange of products and services between individuals (consumers). In tourism, examples of the sharing economy can be found in the following fields [45,46]: (1) accommodation services-in the form of short-term rental of entire houses, flats, or rooms, where both guests and hosts are registered users of a platform, or in the form of home-swapping; (2) transport services-in the form of ride-sharing, as a way of getting from home to a tourist destination (long-distance travel, instead of a train or bus) or moving around as part of the tourist experience (short-distance travel as an alternative to public transport or taxis); (3) catering services-meal-sharing, carried out mainly in private houses in the tourist area; (4) tourist guide services-where the function of a tour guide is performed by residents of a given tourist area. The sharing economy concept is associated with certain behaviors of tourists that may manifest themselves as a result of lifestyle changes across generations. Therefore, the relationship between these constructs should be traced in the literature.

A review of articles on the sharing economy and peer-to-peer accommodation reveals a number of qualitative and quantitative studies directly or indirectly related to the subject of lifestyle. As shown in Table 1, the covered lifestyle contexts included lifestyle in an intercultural context [47]; lifestyle as a driver, result, or part of the sharing economy (or related consumption patterns) $[4,5,9,16,48-50]$; lifestyle threatened by the sharing economy [51]; description of the lifestyles of sharing economy users [52]; sustainable lifestyle [53]; and lifestyle as a direction in research on the sharing economy [54]. In some papers, no direct link between lifestyle and the sharing economy was found [47,50,52], but most included cases of sharing economy accommodation [9,16,47-49,51,52].

The analysis shows that lifestyle has an impact on the behaviors associated with the sharing economy and peer-to-peer accommodation, but that the relationship can also work in the opposite direction. The various opportunities offered by the sharing economy may influence consumers' behaviors and changes in their lifestyles. Contemporary tourists try to avoid the tourism industry by making long-term lifestyle changes and seek authenticity by interacting with locals. Therefore, tourism is not just an industry, it is also negotiated between private individuals, with or without intermediaries, which calls for a rethinking of the concept of "tourism" [17] (p. 297). 
Table 1. Research on lifestyle and the sharing economy in core literature (Web of Science).

\begin{tabular}{|c|c|c|c|c|c|c|}
\hline Aim & Method & Overall Results & $\begin{array}{l}\text { Lifestyle } \\
\text { Context }\end{array}$ & Activity Type & $\begin{array}{l}\text { Sharing Economy-Lifestyle } \\
\text { Links }\end{array}$ & Study \\
\hline $\begin{array}{l}\text { The study investigated } \\
\text { western Airbnb hosts' } \\
\text { experiences with } \\
\text { Chinese outbound } \\
\text { tourists (p. 288). }\end{array}$ & $\begin{array}{l}\text { Four-stage analysis } \\
\text { of hosts' comments. } \\
\text { Co-occurrence } \\
\text { analysis using the } \\
\text { Gephi software }\end{array}$ & $\begin{array}{l}\text { The research highlighted the role that } \\
\text { cultural differences and tradition } \\
\text { play in guest-host encounters, and } \\
\text { offered a theoretical framework on } \\
\text { inter-cultural host-guest relationship } \\
\text { that provides an initial } \\
\text { understanding of this phenomenon. }\end{array}$ & $\begin{array}{l}\text { Lifestyle in an } \\
\text { intercultural } \\
\text { context: western } \\
\text { hosts-Chinese } \\
\text { guests }\end{array}$ & $\begin{array}{l}\text { Peer-to-peer } \\
\text { accommodation }\end{array}$ & $\begin{array}{l}\text { Not directly indicated. } \\
\text { Differences in the represented } \\
\text { lifestyles can affect the } \\
\text { experiences of both hosts and } \\
\text { guests in case of peer-to-peer } \\
\text { accommodation. }\end{array}$ & [47] \\
\hline $\begin{array}{l}\text { The study examined the } \\
\text { nuanced styles of } \\
\text { collaborative } \\
\text { consumption in relation } \\
\text { to market-mediated } \\
\text { access practices and } \\
\text { socially mediated } \\
\text { sharing practices } \\
\text { (p. 692). }\end{array}$ & $\begin{array}{l}\text { Observation, } \\
\text { ethnographic } \\
\text { interviews, and a } \\
\text { netnographic } \\
\text { study }\end{array}$ & $\begin{array}{l}\text { The research identified three styles } \\
\text { of collaborative consumption: } \\
\text { communal (pro-social), consumerist } \\
\text { (commercial), and opportunistic } \\
\text { (exploitative). }\end{array}$ & $\begin{array}{l}\text { Lifestyle as part } \\
\text { of collaborative } \\
\text { consumption } \\
\text { styles }\end{array}$ & Ridesharing & $\begin{array}{l}\text { Convenient and trendy } \\
\text { lifestyle as a factor influencing } \\
\text { the consumerist collaborative } \\
\text { consumption style in } \\
\text { ridesharing. }\end{array}$ & [4] \\
\hline $\begin{array}{l}\text { The study } \\
\text { re-established the role } \\
\text { of the Airbnb platform } \\
\text { in contemporary tourist } \\
\text { destination } \\
\text { management (p. 458). }\end{array}$ & $\begin{array}{l}\text { Critical approach to } \\
\text { regulatory measures }\end{array}$ & $\begin{array}{l}\text { The findings indicated that } \\
\text { restrictions on Airbnb are often } \\
\text { unfounded. This is due to } \\
\text { preconceptions regarding the impact } \\
\text { on traditional hotels and the } \\
\text { preservation of local lifestyles, rather } \\
\text { than specific and objective } \\
\text { measurements of impact. }\end{array}$ & $\begin{array}{l}\text { Local lifestyle at } \\
\text { risk due to the } \\
\text { sharing } \\
\text { economy }\end{array}$ & $\begin{array}{l}\text { Short-term rental } \\
\text { accommodation }\end{array}$ & $\begin{array}{l}\text { The sharing economy is falsely } \\
\text { seen as a threat to the local } \\
\text { lifestyle. Local identity and } \\
\text { lifestyle should be protected } \\
\text { from unregulated sharing } \\
\text { economy development. }\end{array}$ & [51] \\
\hline
\end{tabular}


Table 1. Cont.

\begin{tabular}{|c|c|c|c|c|c|c|}
\hline Aim & Method & Overall Results & $\begin{array}{l}\text { Lifestyle } \\
\text { Context }\end{array}$ & Activity Type & $\begin{array}{l}\text { Sharing Economy-Lifestyle } \\
\text { Links }\end{array}$ & Study \\
\hline $\begin{array}{l}\text { The study described } \\
\text { anti-consumption } \\
\text { lifestyles and the } \\
\text { impact of such lifestyles } \\
\text { on the acceptance of } \\
\text { commercial sharing } \\
\text { systems (CSS) (p. 1422). }\end{array}$ & $\begin{array}{l}\text { Structural equation } \\
\text { modeling (SEM) }\end{array}$ & $\begin{array}{l}\text { The findings indicated that } \\
\text { anti-consumption lifestyles consist of } \\
\text { frugality, voluntary simplicity, } \\
\text { environmental protection, small } \\
\text { luxury and tightwadism, and that } \\
\text { they differently influence consumers' } \\
\text { behaviors with respect to using } \\
\text { commercial sharing systems. }\end{array}$ & $\begin{array}{l}\text { Lifestyle as a } \\
\text { major driver of } \\
\text { commercial } \\
\text { sharing system } \\
\quad \text { use }\end{array}$ & $\begin{array}{l}\text { Car and } \\
\text { accommodation } \\
\text { sharing services }\end{array}$ & $\begin{array}{l}\text { The use of commercial sharing } \\
\text { systems results from different } \\
\text { anti-consumption lifestyles. } \\
\text { Lifestyle trends of reducing } \\
\text { consumption have emerged } \\
\text { with the growth of the sharing } \\
\text { economy. }\end{array}$ & [9] \\
\hline $\begin{array}{l}\text { This paper presented } \\
\text { the results of an } \\
\text { in-depth study into } \\
\text { Italian home-swappers } \\
\text { and discussed their } \\
\text { socio-economic profiles, } \\
\text { motivations, and } \\
\text { lifestyles (p. 202). }\end{array}$ & $\begin{array}{l}\text { Self-administered } \\
\text { online survey }\end{array}$ & $\begin{array}{l}\text { The findings indicated that } \\
\text { home-swapping is an alternative } \\
\text { form of tourism which requires trust, } \\
\text { open-mindedness, inventiveness, } \\
\text { enthusiasm, and flexibility. }\end{array}$ & $\begin{array}{c}\text { Well-defined } \\
\text { lifestyles as a } \\
\text { driver of } \\
\text { home-swapping }\end{array}$ & Home-swapping & $\begin{array}{l}\text { In the case of the sharing } \\
\text { economy (home-swapping), } \\
\text { there is an overlap with other } \\
\text { social practices present among } \\
\text { niche consumers who are more } \\
\text { concerned about the } \\
\text { environment and more willing } \\
\text { to respond to these concerns by } \\
\text { changing their own lifestyle } \\
\text { and consumption practices. }\end{array}$ & [16] \\
\hline $\begin{array}{l}\text { The study developed a } \\
\text { method to understand } \\
\text { users' lifestyles based } \\
\text { on their interactions } \\
\text { with social networks } \\
\text { (p. 1). }\end{array}$ & $\begin{array}{l}\text { OWA (ordered } \\
\text { weighted averaging) } \\
\text { and hierarchical } \\
\text { clustering }\end{array}$ & $\begin{array}{l}\text { The selected partition for the Airbnb } \\
\text { case defined a set of seven clusters. } \\
\text { Six of them represented a different } \\
\text { lifestyle. }\end{array}$ & $\begin{array}{l}\text { Qualitative } \\
\text { description of } \\
\text { lifestyle }\end{array}$ & $\begin{array}{l}\text { Dining in } \\
\text { peer-to-peer } \\
\text { accommodation } \\
\text { (Airbnb) }\end{array}$ & $\begin{array}{l}\text { Not directly indicated. } \\
\text { The various lifestyle } \\
\text { descriptions were determined } \\
\text { based on characteristics } \\
\text { obtained from comments from } \\
\text { Airbnb accommodation users. }\end{array}$ & [52] \\
\hline
\end{tabular}


Table 1. Cont.

\begin{tabular}{|c|c|c|c|c|c|c|}
\hline Aim & Method & Overall Results & $\begin{array}{l}\text { Lifestyle } \\
\text { Context }\end{array}$ & Activity Type & $\begin{array}{l}\text { Sharing Economy-Lifestyle } \\
\text { Links }\end{array}$ & Study \\
\hline $\begin{array}{l}\text { The study investigated } \\
\text { how the sharing } \\
\text { economy enables a } \\
\text { digital platform to } \\
\text { impact the way of life of } \\
\text { Airbnb hosts (p. 794). }\end{array}$ & $\begin{array}{l}\text { In-depth and } \\
\text { semi-structured } \\
\text { interviews }\end{array}$ & $\begin{array}{l}\text { This shift in the sharing economy } \\
\text { due to financial imperatives shows } \\
\text { how much this field has been } \\
\text { promoting the creation of new } \\
\text { digital monopolies and the } \\
\text { permanence of labor precariousness } \\
\text { scenarios. People subject themselves } \\
\text { to new forms of production that } \\
\text { capitalize on their own intimacy. }\end{array}$ & $\begin{array}{l}\text { Lifestyle } \\
\text { changes as a } \\
\text { result of being } \\
\text { an Airbnb host }\end{array}$ & $\begin{array}{l}\text { Peer-to-peer } \\
\text { accommodation }\end{array}$ & $\begin{array}{l}\text { Transforming the home into a } \\
\text { commercial space forces hosts } \\
\text { to adopt new social behaviors, } \\
\text { and to acquire a new lifestyle. } \\
\text { The contribution of hosting in } \\
\text { the sharing economy is to } \\
\text { challenge traditional social } \\
\text { values. }\end{array}$ & {$[48]$} \\
\hline $\begin{array}{l}\text { The study explored the } \\
\text { factors influencing } \\
\text { consumer adoption of } \\
\text { Airbnb. }\end{array}$ & Online survey & $\begin{array}{l}\text { Performance expectancy, social } \\
\text { influence, hedonic motivation, and } \\
\text { price value are significant predictors } \\
\text { of intention to use Airbnb. } \\
\text { Consumers' trust is positively } \\
\text { related to performance expectancy. } \\
\text { Consumers' cross-cultural } \\
\text { experience moderates the } \\
\text { relationship between performance } \\
\text { expectancy and behavior intention, } \\
\text { and consumers' extroversion. } \\
\text { Change-seeking tendency moderates } \\
\text { the relationship between hedonic } \\
\text { motivation and behavior intention. }\end{array}$ & $\begin{array}{l}\text { "Airbnb" as a } \\
\text { new lifestyle }\end{array}$ & $\begin{array}{l}\text { Short-term rental } \\
\text { accommodation }\end{array}$ & $\begin{array}{l}\text { The sharing economy appeals } \\
\text { to those seeking change. } \\
\text { Change-seeking refers to the } \\
\text { demand for stimuli that a } \\
\text { person needs to keep oneself in } \\
\text { the best condition. It is a } \\
\text { curiosity-motivated and } \\
\text { variety-seeking behavior. } \\
\text { Since Airbnb provides a lot of } \\
\text { lodging types, change seekers } \\
\text { are more likely to enjoy this } \\
\text { feature. }\end{array}$ & [49] \\
\hline $\begin{array}{l}\text { The study identified a } \\
\text { new consumer } \\
\text { materialism } \\
\text { within the sharing } \\
\text { economy (p. 1). }\end{array}$ & $\begin{array}{c}\text { Surveys collected } \\
\text { during various } \\
\text { events }\end{array}$ & $\begin{array}{l}\text { Traditional materialism, i.e., the } \\
\text { ownership and accumulation of } \\
\text { goods, is losing its importance in } \\
\text { favor of new materialism. } \\
\text { Materialism is evolving from a mere } \\
\text { static accumulation of goods } \\
\text { towards a hybrid model (property } \\
\text { and the enjoyment of goods coexist } \\
\text { with the enjoyment of experience). }\end{array}$ & $\begin{array}{c}\mathrm{New} \\
\text { materialism as a } \\
\text { lifestyle }\end{array}$ & $\begin{array}{l}\text { Sharing economy } \\
\text { in general }\end{array}$ & $\begin{array}{l}\text { The sharing economy can be a } \\
\text { business model that will } \\
\text { change consumers' relationship } \\
\text { to objects and the materialistic } \\
\text { lifestyle. Changes in lifestyles } \\
\text { caused by the economic crisis } \\
\text { could lead to a reduction in the } \\
\text { excessive consumption of } \\
\text { goods and promote more } \\
\text { responsible consumer behavior. }\end{array}$ & [5] \\
\hline
\end{tabular}


Table 1. Cont.

\begin{tabular}{|c|c|c|c|c|c|c|}
\hline Aim & Method & Overall Results & $\begin{array}{l}\text { Lifestyle } \\
\text { Context }\end{array}$ & Activity Type & $\begin{array}{l}\text { Sharing Economy-Lifestyle } \\
\text { Links }\end{array}$ & Study \\
\hline $\begin{array}{l}\text { The study investigated } \\
\text { the readiness of the } \\
\text { young generation to } \\
\text { face the challenge of } \\
\text { changing their lifestyle } \\
\text { based on unlimited } \\
\text { consumption towards } \\
\text { one that will take } \\
\text { sustainability into } \\
\text { account as a basis for } \\
\text { consumer behavior } \\
\text { (p. 179). }\end{array}$ & $\begin{array}{c}\text { CAWI } \\
\text { (Computer-Assisted } \\
\text { Web Interview) } \\
\text { method and online } \\
\text { interviews }\end{array}$ & $\begin{array}{l}\text { The quality of life, in the context of } \\
\text { responsible development, requires a } \\
\text { change in the way of thinking and } \\
\text { philosophy of life, recognition of } \\
\text { new values and lifestyles, and } \\
\text { different shaping of living conditions. } \\
\text { This includes changing consumer } \\
\text { habits, which would contribute to } \\
\text { changing lifestyles and thus } \\
\text { reducing environmental damage. }\end{array}$ & $\begin{array}{l}\text { Lifestyle results } \\
\text { from } \\
\text { consumption } \\
\text { patterns }\end{array}$ & $\begin{array}{l}\text { Freeganism (the } \\
\text { reuse of food that } \\
\text { has been thrown } \\
\text { away or is to be } \\
\text { thrown away) }\end{array}$ & $\begin{array}{l}\text { Not directly indicated. } \\
\text { Lifestyle results from consumer } \\
\text { behavior. The method of } \\
\text { consumption and striving for } \\
\text { its rational dimension } \\
\text { contribute to changing } \\
\text { consumer habits and lifestyle, } \\
\text { and to reducing environmental } \\
\text { damage. The sharing economy } \\
\text { can be the solution. }\end{array}$ & {$[50]$} \\
\hline $\begin{array}{l}\text { The study investigated } \\
\text { how trust and } \\
\text { regulation shape } \\
\text { relations between } \\
\text { providers and } \\
\text { consumers in the } \\
\text { sharing economy (p.1). }\end{array}$ & Literature review & $\begin{array}{l}\text { Most sharing economy research is } \\
\text { not focused on sustainability. } \\
\text { Some areas of the sharing economy } \\
\text { are conducive to sustainable } \\
\text { development, others are conducive } \\
\text { to social cohesion and ultimately } \\
\text { build social capital, while still others } \\
\text { focus on comfort and lifestyle. }\end{array}$ & $\begin{array}{l}\text { Sustainable } \\
\text { lifestyle }\end{array}$ & $\begin{array}{l}\text { Sharing economy } \\
\text { in general }\end{array}$ & $\begin{array}{l}\text { Adopting a sustainable lifestyle } \\
\text { can reduce the exploitation of } \\
\text { natural resources. The sharing } \\
\text { economy is part of a } \\
\text { sustainable lifestyle-it offers } \\
\text { and shares underutilized } \\
\text { resources. }\end{array}$ & [53] \\
\hline $\begin{array}{l}\text { The study uncovered } \\
\text { the theoretical } \\
\text { foundations and key } \\
\text { themes underlying the } \\
\text { sharing economy. }\end{array}$ & $\begin{array}{c}\text { Systematic } \\
\text { literature review }\end{array}$ & $\begin{array}{l}\text { There are three distinct areas within } \\
\text { the sharing economy literature and } \\
\text { two areas specific to tourism and } \\
\text { hospitality: the sharing economy's } \\
\text { impact on destinations and tourism } \\
\text { services, and the sharing economy's } \\
\text { impact on tourists. Five research } \\
\text { streams were identified: lifestyle and } \\
\text { social movement, consumption, } \\
\text { sharing, trust, and innovation. }\end{array}$ & $\begin{array}{l}\text { Lifestyle as one } \\
\text { of the research } \\
\text { streams }\end{array}$ & $\begin{array}{l}\text { Sharing economy } \\
\text { in general }\end{array}$ & $\begin{array}{l}\text { The sharing economy has a } \\
\text { strong intellectual tradition in } \\
\text { the lifestyle and social } \\
\text { movement field, consumption } \\
\text { practices, and the sharing } \\
\text { paradigm. Lifestyle is a } \\
\text { primary means to foster social } \\
\text { change. }\end{array}$ & {$[54]$} \\
\hline
\end{tabular}

Source: Authors' own work. 


\subsection{Motivations for Activities Pertaining to the Sharing Economy}

In the sharing economy, the traditional concept of renting or sharing has changed and become more efficient, intelligent, and human-centered [55,56], and this does not mean that users do not buy anything, just that they do not have to buy everything [55] (p.87). Relinquishing the former attachment to ownership and replacing it with temporary access to underused assets can be motivated by many factors. The most common motivations for participating in the sharing economy in tourism are financial ones, including savings and lower transaction costs [1,2,23-27], and non-financial ones, related to care for the environment, social responsibility, enjoyment, and meeting new people $[7,23,24,39]$. In the existing studies on motivations for using peer-to-peer accommodation, various groups of factors were taken into consideration (see Table 2), but in most, economic and social factors were the strongest.

Table 2. Motivation for peer-to-peer accommodation use.

\begin{tabular}{cc}
\hline Variable & Study \\
\hline Cost savings, familiarity, trust, utility & {$[2]$} \\
\hline Social appeal, economic appeal & {$[24]$} \\
\hline Enjoyment, perceived network effect & {$[56]$} \\
\hline Enjoyment, monetary benefits, accommodation amenities & {$[27]$} \\
\hline Enjoyment, independence through ownership, modern lifestyle, social experience & {$[28]$} \\
\hline Interaction, home benefits, novelty, sharing economy ethos, local authenticity & {$[29]$} \\
\hline
\end{tabular}

The behavior of some sharing economy consumers is economically motivated, while for others it is driven by social and environmental factors. Decisions related to tourism and leisure are affected by a system of beliefs comprising a certain mindset. Many lifestyle-related factors influence the intention of consumers to use the sharing economy and their eventual behavior (see Figure 1). Therefore, for the purpose of the analysis, the authors categorized motivations in accordance with the represented lifestyle. The selection of sharing economy services can result from the following motivations:

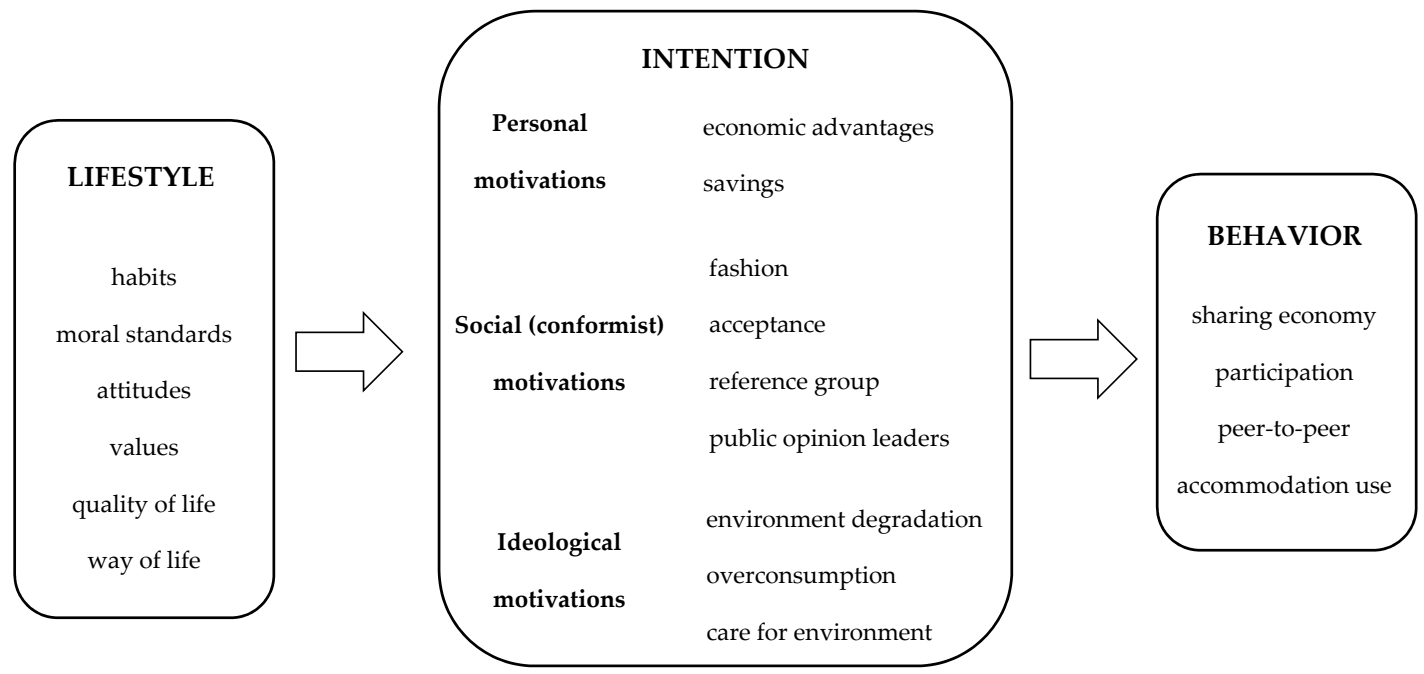

Figure 1. The impact of lifestyle on the intention to participate in the sharing economy and to use peer-to-peer accommodation. Source: Authors' own work.

(1) Personal motivations, related to economic advantages and potential financial savings. Tourists choose sharing economy activities because it is more financially reasonable for them and their families, and allows them to visit many interesting places at a lower cost than in the case of regular hotel accommodation or transportation. 
(2) Social (conformist) motivations. They result from the need to fit in with others, as well as from acceptance of the shifts and processes taking place in contemporary society, e.g., increasing environmental awareness. These motivations can be the result of pressure from the society, reference groups, public opinion leaders, as well as (or maybe primarily) producers and service providers. Potential consumers are influenced by them due to their own beliefs or the need to conform to the society in which they function. The selection of sharing economy services can result from a wish to follow leaders or from a short-lived trend for traveling "off the beaten path" and interacting with the locals.

(3) Ideological motivations. These motivations result from their awareness of processes such as natural environment degradation and excessive consumption, as well as their genuine desire to prevent these processes out of care for the future. In those motivations one can find the strongest manifestation of increased environmental awareness and opposition to excessive consumption.

Increased social development means that more and more people may want not only to improve their own living conditions, but also to look for authentic experiences, protect the environment, and take care of the future of the Earth, all of which can lead to participation in the sharing economy. Consumers are becoming aware of the relationship between their behavior and other aspects of social and economic life. They discover that their shopping decisions can affect the environment in which they live, thus impacting the quality of both their own life and the life of the entire society and the communities they visit.

\section{Materials and Methods}

In the study, both secondary and primary sources of data were used. First, a review of relevant literature on lifestyle, the sharing economy, and peer-to-peer accommodation was conducted (presented above). It included scientific articles indexed in Web of Science databases, published in the last 10 years, since 2010 (last updated: 7 March 2020). The articles were searched according to the following search terms: "sharing economy and lifestyle", "peer-to-peer accommodation and lifestyle", and "Airbnb and lifestyle". A total of 43 results were found. After the removal of duplicates and a preliminary analysis of abstracts, 12 papers were included in the detailed content analysis (Appendix A). The literature review was supplemented by articles related to the subject of the study, but not included in the Web of Science database. The literature review was performed to establish a link between lifestyle and the sharing economy and motivations for peer-to-peer accommodation selection, and to provide a basis for empirical research.

The empirical part of the study was devoted to the relationship between lifestyle changes and willingness to use sharing economy services, with an emphasis on accommodation. The aim was to answer the question: which motivations resulting from the respondents' lifestyle affect their willingness to use peer-to-peer accommodation? In order to achieve this, it was first necessary to analyze this relationship in a broader context, i.e., by assessing respondents' sense of responsibility for the use of resources, importance of sustainability in individual actions, and motives for engaging in sharing economy activities such as transportation, food, and equipment sharing, or clothes swapping. In order to gather opinions and to understand behaviors, attitudes, and preferences regarding the use of sharing economy services, the focus group interview method was used. This method is particularly helpful for an exploratory investigation of new phenomena [57]. The study was carried out in 6 groups, with 5-8 participants each.

The most important factors differentiating motivations for choosing particular accommodation types are age, educational level, and household income [18]. Therefore, the study was carried out in two relevant populations, with 3 groups per population. One population consisted of young people—students, with low incomes, relatively abundant free time, and no life responsibilities (young with time, YT). Previous studies reported that young people in Poland are educated in the spirit of environmental awareness and concern for the natural environment. A moderate stability of behavior and inclination towards de-consumption was observed in this population [58]. The other population 
consisted of subjects with higher incomes, aged between 40 and 50, with a wealth of life experience, who demonstrate their genuine attitudes through autonomous, financially unlimited shopping decisions (older rich, OR). One might assume that the latter group manifests their lifestyle preferences through their shopping decisions.

Group discussions were carried out separately for the two populations (3 groups per population), which made it possible to seek differences and similarities between the behaviors of respondents who differed in terms of age and financial status. The key issue for the study was the focus on the behavioral aspect of respondents' attitudes. Therefore, as well as their declarations about whether they performed certain actions, the authors examined respondents' motivations behind choosing (or not choosing) sharing economy activities.

In the first part of the group discussions, general questions were asked in order to determine respondents' lifestyles and their openness towards the sharing economy. Understanding the general attitude of the respondents made it possible to examine hidden motives resulting from lifestyle changes in the context of tourism. Then, the discussion focused on the motivations for selecting sharing economy services (the sharing of transportation, food, clothes, equipment, accommodation), resulting from the subjects' lifestyles. Group discussions were not structured in nature, and the role of the moderator was simply to direct the conversation. The interviews were carried out in June 2019, then transcribed and coded; this was followed by a synthesis of the collected material.

\section{Results of the Empirical Study}

\subsection{Global Waste of Resources}

Since the sharing economy is essentially based on concern for the proper utilization of assets, the first part of the study was devoted to the subject of global waste of resources. All studied groups in the YT population pointed out that food waste is a very serious problem. It was also noted that this problem is present at all levels-in single households, local communities, and entire countries. In one of the groups, a direct remark concerning hotels was made-it was pointed out that "throwing away food in hotels" is a great problem. The YT population clearly indicated that the most important motivation to limit waste is concern for other, poorer countries. This indicated an ideological motivation. Regarding food waste, some respondents said it should be avoided as it is uneconomical for households (personal motivations).

In the OR group, the problem of wasting resources was only mentioned in the context of an increased amount of rubbish, particularly plastics. Motivation to prevent the waste of resources was not observed in any of the OR groups. In the YT population, the problem of the growing amount of rubbish was considered one of the most burning issues in the contemporary world. In two groups, the problem of plastics was mentioned. Smog and environmental pollution were listed as other serious threats. In the OR population, the problem of smog in Poland was also pointed out. Both YT and OR respondents indicated personal motivations as a reason to counteract these problems. Smog damages health, and everyone is to blame for it-individual citizens (who "do not care what goes through their chimneys"), as well as local, national, and European authorities. Both studied populations (YT and OR) agreed that the problem of rubbish is severe, and that sorting is essential. However, the YT population was willing to stop buying expensive products in fancy packaging, while the OR population could not give up this luxury. To sum up, the YT population indicated more environmental threats, e.g., large-scale farming, littering in forests, and excessive logging. In unstructured interviews, OR subjects did not point out these problems. This suggests that the lifestyle of the YT population results from pro-environmental changes. This part of the study was fundamental for the subsequent analysis of lifestyle changes. 


\subsection{Engaging in the Sharing Economy-Transportation, Food, Clothes, and Equipment}

A discussion was initiated regarding the possibilities for engaging in the sharing economy. Young people from the YT group were willing to use shared urban means of transport (bicycles, scooters). Respondents said that it is "cheaper" and "more convenient". In other words, personal motivations prevailed. In the OR population, respondents were not interested in using such means of transport in their place of residence. Most subjects lived in single-family houses in the suburbs and used private cars for transport. One person pointed out that such means of transport are more attractive and fun, and that he used them on holidays. This is confirmed by studies which found that people demonstrate so-called chameleon behavior-during one trip, a tourist can play many roles, e.g., choosing very cheap accommodation and expensive means of transport, saving money on food, and at the same time buying very expensive clothing [59]. Only the YT population admitted to using the Uber service, and only in the YT population was it said that this is good for the environment. Therefore, ideological motivations were present.

In the analysis of lifestyle changes, the attitude towards "healthy eating" was an important issue. The results regarding this topic are quite astonishing. In all OR groups, the subjects emphasized the need to lead a healthy lifestyle. All women recommended "healthy eating", and their motivations were of a personal and conformist character. In the younger YT group, there were no clear declarations that "healthy eating is better" - quite the opposite. Several people emphasized that "everyone is free to choose and eat what they want", and even made statements like "I like junk food a lot". The wealthier OR respondents said they read labels out of concern for their own health (personal motivation), while the YT groups admitted to paying no attention to such information.

Another subject discussed was the so-called "breakfast markets", an alternative to preparing meals at home, which may be considered part of the sharing economy. The YT groups demonstrated willingness to try out this option "out of curiosity". The OR groups elaborated on this subject. Respondents thought that such initiatives were "extremely attractive for tourists". One person participated in the organization of such an event for charity, and was proud they had a chance to help others. Therefore, one might observe ideological motivations associated with concern for others.

Another topic of discussion was clothes swapping. In the OR group, it was pointed out that this is a way to "get rid of clothes" - the respondents did not undertake similar actions to help others or the environment. The YT groups presented an entirely different attitude-they admitted to participating in such swaps or buying clothes in second-hand shops. The following motivations were listed: saving money, a desire to have original clothing, and doing something for the environment (economic, personal, and ideological motivations). Respondents in one of the YT groups pointed out a serious problem of the excessive production of clothing by chain stores. In the OR group, the discussion of the problem of buying new clothing led to the conclusion that "one should follow trends", i.e., conformist attitudes were manifested. None of the OR respondents admitted to wearing second-hand clothes, as opposed to the young YT subjects.

Lifestyle changes can also be observed in attitudes towards wearing natural fur and leather goods. Wealthy OR respondents noticed the problem associated with fur-bearing animals, but emphasized that they "would not give up wearing leather shoes and bags". The YT groups clearly stated that wearing leather goods contradicts the modern lifestyle.

The analysis of the sharing economy also included the rental of various pieces of equipment or appliances. Responses in the two populations differed. The OR population did not see the need to use other people's equipment- they actually made it very clear that their status was related to buying things. Furthermore, as a result of conformist motivations, they demonstrated consumerist attitudes, e.g., replacing kitchen appliances, cars or pieces of furniture regardless of their condition-just to show off their status and be fashionable. There was also a discussion of "how good you look when you buy a new boat". In two YT groups, different attitudes were manifested. Several subjects made arguments that renting equipment is a good and useful habit, and that their families cultivated such a habit with their neighbors, with no cash involved. There was even an opinion that "in the countryside, you would 
buy one machine for three farms, and you use it in turn". However, in this group, some also manifested concern and a lack of trust when lending one's own equipment to others, which seems quite surprising in the case of young people. Differences between small towns and large cities were pointed out: in the latter, the level of trust is considerably lower, as people do not know one another. Such an attitude can also result from Polish historical heritage, which has led to a significant decrease in the level of social trust. What Poles experienced caused a certain social and cultural trauma (probably passed from generation to generation), which undoubtedly led to the emergence of the "crisis syndrome" and lack of trust [60].

\subsection{Travel Patterns, Peer-to-Peer Accommodation}

The above problems were fundamental for the analysis of lifestyle changes. The next part of the study mainly focused on the influence of these changes on the way people travel, including the choice of peer-to-peer accommodation. In all OR groups, the respondents admitted to using the Airbnb platform. They emphasized that they choose places with a high standard of services. The respondents used this service, as it is more economical and provides an option to stay with a larger group of friends or acquaintances. The subjects pointed out that access to kitchen facilities is important, because they can make "healthy food" any time they want. This reinforces the view that wealthier people follow certain diets, and that they are motivated by personal benefits. In this population, the subjects expressed criticism towards large hotels, unattractive for wealthier people who traveled a lot. There is also a need to stand out, resulting from trends and the influence of social groups. It is not "cool" to travel to popular holiday destinations. It can be concluded that the selection of peer-to-peer accommodation results from personal and conformist motivations. In the OR group, using shared accommodation was not mentioned as an activity leading to the protection of resources. Respondents from the YT population made similar observations regarding the use of such services: "It is not about the environment; it is about money. It is budget-friendly". Therefore, in this population, personal motivations prevailed. Other important benefits of using Airbnb or Couchsurfing were also observed in this group: "We can live in one flat with a local person, we can learn more and have a free tour guide".

The discussion indicated that YT respondents are more open to new experiences and trying out new solutions. In one group, staying at a luxurious "all-inclusive" hotel was mentioned as something new. For people who are used to organizing trips on their own, staying at such hotels is attractive. According to the subjects "you do not have to follow the trends". It is an example of the lack of a conformist approach. The topic of cleaning house, both at home and on holidays, was also discussed. None of the populations had any problem with using professional cleaning services. In the OR group, criticism of absolute reliance on professionals was expressed. Wealthy people noticed that it impaired the independence of their own, almost adult children. It was pointed out that even on holidays, it is "not good" if the children do not have a habit of cleaning up after themselves, and that they should be included in daily chores. According to the respondents, peer-to-peer accommodation can "teach you real life". In the YT groups there were opinions voiced that "hiring cleaning staff is nothing unusual". There were economic motivations: a respondent claimed that "if I make more money per hour in my job than I pay the cleaning person, it makes more sense economically".

The discussion of changes in attitudes towards tourist trips was concluded with a question about which is better: a package holiday or an independently organized trip. In the groups of wealthy subjects, it was pointed out that typical package holidays are not "trendy". Only one person praised such holidays, but this was because it had been a new experience for them. Other people wanted to be perceived as "travelers", and organizing one's travels independently was seen as manifestation of this status. Detailed questions demonstrated that travel, for the OR groups, was not entirely independent. In three groups, local guides were booked; in one, an agency was used for organizing accommodation, and in another for booking transport.

In the YT population, all groups of respondents said that trips organized independently and individually are "definitely" preferable. The following advantages were mentioned: "we are not 
dependent on anybody", "we can adjust the budget to our possibilities", "we can plan everything on our own", and "we decide how much time we want to spend there". In these groups, it was also noted, though, that package holidays may at times be more attractive in terms of pricing and offer. The main motivation for organizing one's holidays individually was conformist for the OR population, and personal for the YT population. No ideological motivations were present in the discussion.

\section{Discussion and Conclusions}

Decisions of how to use tourist services can result from specific lifestyles and lifestyle changes. For the purpose of the article, the authors divided motivations for the selection of accommodation services and other collaborative consumption activities into personal, conformist, and ideological. The study was conducted in two populations of respondents: (1) young, with a lot of free time and limited income, and (2) wealthy, aged between 40 and 50, with rich life experience; and demonstrated lifestyle changes between the generations. The findings are as follows: (1) Subjects from the YT population are more aware of environmental threats and are more concerned about the environment. Their actions result not only from personal motivations (financial savings) but also ideological ones. The YT subjects are also interested in participating in sharing economy activities: they are more willing to use shared means of transport, participate in clothing swaps, and rent equipment and appliances than the OR subjects. (2) The OR population leads a lifestyle that is mainly based on personal (often conformist) motivations, which result from the influence of social groups. They aim at staying healthy and lead a so-called "healthy lifestyle". Subjects from the YT population do not express too much interest in healthy eating and reading labels, while the subjects from the OR group do. (3) All groups of respondents prefer independent travel, but for different reasons. Young people seek interaction with the local community, while older and wealthier people who have already traveled a lot want to show off as "travelers", not "tourists". Their decisions are also affected by social judgment. (4) When it comes to using peer-to-peer accommodation, YT respondents are more open to new experiences and trying out new solutions. OR respondents are driven to use these types of services because of personal economic benefits and convenience. (5) Neither population recognizes a relationship between participating in the sharing economy on the one hand, and caring for the environment and preventing excessive consumption on the other. The final classification of motivations in both groups is presented in Table 3.

Several conclusions can be drawn based on these findings:

1. The lack of a relationship between participation in the sharing economy and care for the environment is in contrast with some studies on motives for participating in the sharing economy in tourism and using peer-to-peer accommodation $[16,24,61]$. This could indicate that sharing economy business models may not be seen by consumers as sustainable or environmentally friendly. However, this finding does correspond to the economically and socially motivated behaviors reported in previous studies. Therefore, more attention should be paid to sustainability issues. Although the sharing economy model was conceived as an answer to over-consumption and the waste of resources, in reality, consumers pay more attention to financial and social benefits. By participating in sharing economy activities, they tend to contribute to reducing resource use in an unconscious and unintentional way.

2. The results may be useful for companies that would like to operate according to a sustainable business model, which includes creating value for the customer in accordance with the principles of sustainable development. When constructing their own business models, companies should consider the overall lifestyle changes that characterize both groups of respondents (potential customers) and the importance of new customers' preferences. These preferences should be taken into account in the creation of extended and potential components of business models, which may give a competitive advantage to traditional businesses in the tourism market (accommodation, transport, catering). 
3. The study shows differences between the two generations in terms of lifestyle, sense of responsibility for the use of resources, and motivations for participating in the sharing economy and for the specific organization of travel and use of peer-to-peer accommodation. In planning activities to promote sustainable consumption and sustainable business models, one should take these differences into account and highlight diverse lifestyle aspects in messages to both groups.

4. The study was exploratory in nature and only included Polish respondents, but it should be noted that in the era of globalization, the needs and preferences of consumers may not necessarily differ between countries. People from both surveyed segments, YT and OR, can model their lifestyles on those found in other countries due to the frequency of travel and possibilities of communication using new technologies.

Table 3. Respondents' motivations for sharing economy activities.

\begin{tabular}{ccc}
\hline Activities & \multicolumn{2}{c}{ Motivations } \\
YT & OR \\
\hline Prevention of wasting resources & $\begin{array}{c}\text { Ideological, } \\
\text { personal }\end{array}$ & None \\
\hline Healthy eating & $\begin{array}{c}\text { Personal, } \\
\text { ideological }\end{array}$ & Personal \\
\hline Attending “breakfast markets" & None & $\begin{array}{c}\text { Personal, } \\
\text { conformist }\end{array}$ \\
\hline Using means of transport associated with the sharing economy y & $\begin{array}{c}\text { Personal, } \\
\text { ideological }\end{array}$ & Personal \\
\hline Swapping clothes & $\begin{array}{c}\text { Personal, } \\
\text { ideological }\end{array}$ & None \\
\hline Renting equipment & $\begin{array}{c}\text { Personal, } \\
\text { ideological }\end{array}$ & None \\
\hline Using peer-to-peer accommodation & Personal & Personal, \\
\hline Individual organization of holidays & Personal & Conformist \\
\hline
\end{tabular}

Source: Author's own work. Abbreviations: YT, young with time; OR, older rich.

The authors are aware that the selected research method does not produce representative results and entire populations may not be assessed based on the data acquired in this manner. Nonetheless, the subject of consumers' behaviors required a qualitative data collection method to explain the discussed topic in more detail (e.g., to establish an informational background, propose ideas, detect needs, formulate hypotheses, etc.). Due to the broad scope of the problem and the preliminary character of the analysis, the study was strictly exploratory.

The study was conducted in two populations of respondents, differing in terms of their age and income. One must take into account that sociological analyses also suggest other qualities that may be used to differentiate segments of buyers. It was shown that the studied YT and OR populations are significantly different in terms of the presented lifestyles and motivations for participating in activities pertaining to the sharing economy, including the organization of holidays and choosing accommodation. Quantitative studies should be carried out in the future to verify whether the presented motivations are consistent with the observations made in the studied populations. Another potential research subject would be the analysis of why young Poles tend to be distrustful, especially since previous studies listed young people as the most eager to use sharing economy services (also in tourism) [2,62-64]. 
Author Contributions: Conceptualization, A.N. and K.K.; Methodology, A.N. and K.K.; Supervision, A.N. and K.K.; Visualization, A.N. and K.K.; Writing—original draft, A.N. and K.K.; Writing-review and editing, A.N. and K.K. All authors have read and agreed to the published version of the manuscript.

Funding: This research received no external funding.

Conflicts of Interest: The authors declare no conflict of interest.

\section{Appendix A}

List of papers included in the systematic literature review (Web of Science)

1. Cheng, M.; Zhang, G. When Western hosts meet Eastern guests: Airbnb hosts' experience with Chinese outbound tourists. Ann. Tour. Res. 2019, 75, 288-303.

2. Guyader, H. No one rides for free! Three styles of collaborative consumption. J. Serv. Mark. 2018, 32, 692-714.

3. Avdimiotis, S.; Poulaki, I. Airbnb impact and regulation issues through destination life cycle concept. Int. J. Cult. Tour. Hosp. Res. 2019, 13, 458-472.

4. Lee, H.J. The effect of anti-consumption lifestyle on consumer's attitude and purchase intention toward commercial sharing systems. Asia Pacific J. Mark. Logist. 2019, 31, 1422-1441.

5. Forno, F.; Garibaldi, R. Sharing Economy in Travel and Tourism: The Case of Home-Swapping in Italy. J. Qual. Assur. Hosp. Tour. 2015, 16, 202-220.

6. Nguyen, J.; Armisen, A.; Sánchez-Hernández, G.; Casabayó, M.; Agell, N. An OWA-based hierarchical clustering approach to understanding users' lifestyles. Knowledge-Based Syst. 2020, 190, 1-26.

7. Saturnino, R.; Sousa, H. Hosting as a Lifestyle: The Case of Airbnb Digital Platform and Lisbon Hosts. Partecip. E Conflitto 2019, 12, 794-818.

8. Min, W.; Lu, L. Who Wants to Live Like a Local?: An Analysis of Determinants of Consumers' Intention to Choose AirBNB. In Proceedings of the 2017 International Conference on Management Science and Engineering (ICMSE); IEEE, 2017; pp. 642-651.

9. Alonso-Almeida, M. del M.; Perramon, J.; Bagur-Femenías, L. Shedding light on sharing ECONOMY and new materialist consumption: An empirical approach. J. Retail. Consum. Serv. 2020, 52, 1-9.

10. Gierszewska, G.; Seretny, M. Sustainable Behavior-The Need of Change in Consumer and Business Attitudes and Behavior. Found. Manag. 2019, 11, 197-208.

11. Penz, E.; Hartl, B.; Hofmann, E. Collectively Building a Sustainable Sharing Economy Based on Trust and Regulation. Sustainability 2018, 10, 1-6.

12. Cheng, M. Current sharing economy media discourse in tourism. Ann. Tour. Res. 2016, 60, 111-114.

\section{References}

1. Bardhi, F.; Eckhardt, G.M. Access-Based Consumption: The Case of Car Sharing. J. Consum. Res. 2012, 39, 881-898. [CrossRef]

2. Möhlmann, M. Collaborative consumption: Determinants of satisfaction and the likelihood of using a sharing economy option again. J. Consum. Behav. 2015, 14, 193-207. [CrossRef]

3. Skalska, T.; Markiewicz, E.; Pędzierski, M. Konsumpcja kolaboratywna w obszarze turystyki. Próba prezentacji stanu zjawiska na rynku polskim. Folia Tur. 2016, 41, 165-190.

4. Guyader, H. No one rides for free! Three styles of collaborative consumption. J. Serv. Mark. 2018, 32, 692-714. [CrossRef]

5. del Alonso-Almeida, M.M.; Perramon, J.; Bagur-Femenías, L. Shedding light on sharing ECONOMY and new materialist consumption: An empirical approach. J. Retail. Consum. Serv. 2020, 52, 101900. [CrossRef]

6. Böcker, L.; Meelen, T. Sharing for people, planet or profit? Analysing motivations for intended sharing economy participation. Environ. Innov. Soc. Transit. 2017, 23, 28-39. [CrossRef] 
7. Belk, R. You are what you can access: Sharing and collaborative consumption online. J. Bus. Res. 2014, 67, 1595-1600. [CrossRef]

8. Gansky, L. The Mesh—Why the Future of Business Is Sharing; Penguin: London, UK, 2010; ISBN 9780874216561.

9. Lee, H.J. The effect of anti-consumption lifestyle on consumer's attitude and purchase intention toward commercial sharing systems. Asia Pac. J. Mark. Logist. 2019, 31, 1422-1441. [CrossRef]

10. Sobotko, E. Lifestyles in Modern Society and their Impact on the Market Behaviour of the Young Consumers. Ekon. Wrocław Econ. Rev. 2017, 23, 71-83.

11. Patrzałek, W. The Determinants of Young Consumer's Lifestyle. Mark. i Zarz. 2017, 2, 63-71.

12. Mihajlović, I.; Koncul, N. Changes in consumer behaviour-The challenges for providers of tourist services in the destination. Econ. Res. Istraz. 2016, 29, 914-937. [CrossRef]

13. Sarmento, E.; Loureiro, S.; Martins, R. Foodservice tendencies and tourists' lifestyle: New trends in tourism. Rev. Tur. Desenvolv. 2017, 1, 2265-2277.

14. Chon, K.S.; Pizam, A.; Mansfeld, Y. Consumer Behavior in Travel and Tourism; Routledge: London, UK, 2012.

15. Meyer, B. Consumer Behaviours on the Tourism Market. Econ. Probl. Tour. 2014, 4, 135-148.

16. Forno, F.; Garibaldi, R. Sharing Economy in Travel and Tourism: The Case of Home-Swapping in Italy. J. Qual. Assur. Hosp. Tour. 2015, 16, 202-220. [CrossRef]

17. Kannisto, P. Travelling like locals: Market resistance in long-term travel. Tour. Manag. 2018, 67, $297-306$. [CrossRef]

18. Rivero, M.S.; Rangel, C.R.; Caldito, L.A. Analysis of spa tourist motivations: A segmentation approach based on discriminant analysis. Enl. Tour. A Pathmaking J. 2016, 6, 19-43.

19. Nosratabadi, S.; Mosavi, A.; Shamshirband, S.; Kazimieras Zavadskas, E.; Rakotonirainy, A.; Chau, K.W. Sustainable Business Models: A Review. Sustainability 2019, 11, 1663. [CrossRef]

20. Daunorienè, A.; Drakšaitè, A.; Snieška, V.; Valodkienè, G. Evaluating Sustainability of Sharing Economy Business Models. Procedia Soc. Behav. Sci. 2015, 213, 836-841. [CrossRef]

21. Hojnik, J.; Ruzzier, M.; Ruzzier, M.K. Transition towards sustainability: Adoption of eco-products among consumers. Sustainability 2019, 11, 4308. [CrossRef]

22. Popovic, I.; Bossink, B.A.G.; van der Sijde, P.C. Factors influencing consumers' decision to purchase food in environmentally friendly packaging: What do we know and where do we go from here? Sustainability 2019, 11, 7197. [CrossRef]

23. Tussyadiah, I.P.; Pesonen, J. Impacts of Peer-to-Peer Accommodation Use on Travel Patterns. J. Travel Res. 2016, 55, 1022-1040. [CrossRef]

24. Tussyadiah, I.P.; Pesonen, J. Drivers and barriers of peer-to-peer accommodation stay-An exploratory study with American and Finnish travellers. Curr. Issues Tour. 2018, 21, 703-720. [CrossRef]

25. Balck, B.; Cracau, D. Empirical analysis of customer motives in the shareconomy: A cross-sectoral comparison. Working Paper Series, University of Magdeburg. 2015. Available online: www.fww.ovgu.de/fww_media/ femm/femm_2015/2015_02-EGOTEC-pfuspggp6m5tm4cr9hkm6h00i1.pdf (accessed on 10 April 2020).

26. Karlsson, L.; Dolnicar, S. Someone's been sleeping in my bed. Ann. Tour. Res. 2016, 58, 159-162. [CrossRef]

27. Tussyadiah, I.P. Factors of satisfaction and intention to use peer-to-peer accommodation. Int. J. Hosp. Manag. 2016, 55, 70-80. [CrossRef]

28. Hawlitschek, F.; Teubner, T.; Gimpel, H. Understanding the Sharing Economy-Drivers and Impediments for Participation in Peer-to-Peer Rental. In Proceedings of the 49th Hawaii International Conference on System Sciences (HICSS), Koloa, HI, USA, 5-8 January 2016; Volume 4801, pp. 4782-4791.

29. Guttentag, D.; Smith, S.; Potwarka, L.; Havitz, M. Why Tourists Choose Airbnb: A Motivation-Based Segmentation Study. J. Travel Res. 2018, 57, 342-359. [CrossRef]

30. Antonides, G.; Van Raaij, W.F. Consumer Behaviour. A European Perspective; PWN: Warsaw, Poland, 1999.

31. Mazurek-Łopacińska, K.; Sobocińska, M. Virtualization of Marketing Communication in the Context of Population and Lifestyle Changes. Zesz. Nauk. Uniw. Szczecińskiego. Probl. Zarządzania Finans. Mark. 2015, 39, 143-154. [CrossRef]

32. Lim, E.; Arita, S.; Joung, S. Advancing sustainable consumption in Korea and Japan-from re-orientation of consumer behavior to civic actions. Sustainability 2019, 11, 6683. [CrossRef]

33. Bywalec, C. Consumption in Economic Theory and Practice; PWN: Warsaw, Poland, 2007.

34. Mróz, B. Consumerism vs. sustainability: The emergence of new consumer trends in Poland. Int. J. Econ. Policy Emerg. Econ. 2010, 3, 1-15. [CrossRef] 
35. Kadic-Maglajlic, S.; Arslanagic-Kalajdzic, M.; Micevski, M.; Dlacic, J.; Zabkar, V. Being engaged is a good thing: Understanding sustainable consumption behavior among young adults. J. Bus. Res. 2019, 104, 644-654. [CrossRef]

36. Zalega, T. Sustainable Consumption in Consumer. Stud. Ekon. Zesz. Nauk. Uniw. Ekon. Katow. 2019, 82-107.

37. Ting, C.T.; Hsieh, C.M.; Chang, H.P.; Chen, H.S. Environmental consciousness and green customer behavior: The moderating roles of incentive mechanisms. Sustainability 2019, 11, 819. [CrossRef]

38. Lorenzen, J.A. Diderot Effect. In The Wiley Blackwell Encyclopedia of Consumption and Consumer Studies; John Wiley \& Sons: New York, NY, USA, 2015.

39. Hamari, J.; Sjöklint, M.; Ukkonen, A. The sharing economy: Why people participate in collaborative consumption. J. Assoc. Inf. Sci. Technol. 2016, 67, 2047-2059. [CrossRef]

40. Botsman, R.; Rogers, R. What's Mine Is Yours: The rise of Collaborative Consumption; HarperCollins: New York, NY, USA, 2010; ISBN 978-0-06-196354-4.

41. Barnes, S.J.; Mattsson, J. Understanding current and future issues in collaborative consumption: A four-stage Delphi study. Technol. Forecast. Soc. Chang. 2016, 104, 200-211. [CrossRef]

42. Akbar, Y.H.; Tracogna, A. The sharing economy and the future of the hotel industry: Transaction cost theory and platform economics. Int. J. Hosp. Manag. 2018, 71, 91-101. [CrossRef]

43. Germann Molz, J. Social networking technologies and the moral economy of alternative tourism: The case of couchsurfing.org. Ann. Tour. Res. 2013, 43, 210-230. [CrossRef]

44. Liang, L.J.; Choi, H.C.; Joppe, M. Understanding repurchase intention of Airbnb consumers: Perceived authenticity, electronic word-of-mouth, and price sensitivity. J. Travel Tour. Mark. 2018, 35, 73-89. [CrossRef]

45. Dredge, D.; Gyimóthy, S. The collaborative economy and tourism: Critical perspectives, questionable claims and silenced voices. Tour. Recreat. Res. 2015, 40, 286-302.

46. Heo, C.Y. Sharing economy and prospects in tourism research. Ann. Tour. Res. 2016, 58, 166-170. [CrossRef]

47. Cheng, M.; Zhang, G. When Western hosts meet Eastern guests: Airbnb hosts' experience with Chinese outbound tourists. Ann. Tour. Res. 2019, 75, 288-303. [CrossRef]

48. Saturnino, R.; Sousa, H. Hosting as a Lifestyle: The Case of Airbnb Digital Platform and Lisbon Hosts. Partecip. Confl. 2019, 12, 794-818.

49. Min, W.; Lu, L. Who Wants to Live Like a Local?: An Analysis of Determinants of Consumers' Intention to Choose AirBNB. In Proceedings of the 2017 IEEE International Conference on Management Science and Engineering (ICMSE), Guilin, China, 18-20 August 2017; pp. 642-651.

50. Gierszewska, G.; Seretny, M. Sustainable Behavior-The Need of Change in Consumer and Business Attitudes and Behavior. Found. Manag. 2019, 11, 197-208. [CrossRef]

51. Avdimiotis, S.; Poulaki, I. Airbnb impact and regulation issues through destination life cycle concept. Int. J. Cult. Tour. Hosp. Res. 2019, 13, 458-472. [CrossRef]

52. Nguyen, J.; Armisen, A.; Sánchez-Hernández, G.; Casabayó, M.; Agell, N. An OWA-based hierarchical clustering approach to understanding users' lifestyles. Knowl. Based Syst. 2020, 190, 1-26. [CrossRef]

53. Penz, E.; Hartl, B.; Hofmann, E. Collectively Building a Sustainable Sharing Economy Based on Trust and Regulation. Sustainability 2018, 10, 3754. [CrossRef]

54. Cheng, M. Sharing economy: A review and agenda for future research. Int. J. Hosp. Manag. 2016, 57, 60-70. [CrossRef]

55. Palos-Sanchez, P.R.; Correia, M.B. The collaborative economy based analysis of demand: Study of airbnb case in Spain and Portugal. J. Theor. Appl. Electron. Commer. Res. 2018, 13, 85-98. [CrossRef]

56. Sung, E.; Kim, H.; Lee, D. Why do people consume and provide sharing economy accommodation?-A sustainability perspective. Sustainability 2018, 10, 2072. [CrossRef]

57. Mansourian, Y. Exploratory nature of, and uncertainty tolerance in, qualitative research. New Libr. World 2008, 109, 273-286. [CrossRef]

58. Niezgoda, A.; Markiewicz, E. Lifestyle and Ecological Awareness of Consumers in the Tourist Market-Relations, Conditions and Problems. Ekon. Wroc. Econ. Rev. 2017, 23, 49-62.

59. Niezgoda, A. Wpływ mody na rozwój turystyki. In Wspótczesne Uwarunkowania i Problemy Rozwoju Turystyki; Pawlusiński, R., Ed.; Instytut Geografii i Gospodarki Przestrzennej Uniwersytet Jagielloński w Krakowie: Kraków, Poland, 2013; pp. 85-92.

60. Sztompka, P. Zaufanie. Fundament Społeczeństwa; Znak: Kraków, Poland, 2007. 
61. Tussyadiah, I.P. An Exploratory Study on Drivers and Deterrents of Collaborative Consumption in Travel. In Proceedings of the Information and Communication Technologies in Tourism 2015, Lugano, Switzerland, 3-6 February 2015; Tussyadiah, I., Inversini, A., Eds.; Springer: Cham, Switzerland, 2015; pp. 817-830.

62. Owyang, J.; Tran, C.; Silva, C. The Collaborative Economy: Products, Services, and Market Relationships Have Changed as Sharing Startups Impact Business Models. To Avoid Disruption, Companies Must Adopt the Collaborative Economy Value Chain; Altimeter: San Mateo, UK, 2013.

63. Rostek, A.; Zalega, T. Konsumpcja kolaboratywna wśród młodych polskich i amerykańskich konsumentów (cz. 1). Mark. Rynek 2015, 5, 11-19.

64. Skalska, T. Sharing economy in the tourism market: Opportunities and threats. Kwart. Nauk. Uczel. Vistula 2017, 4, 248-260.

(C) 2020 by the authors. Licensee MDPI, Basel, Switzerland. This article is an open access article distributed under the terms and conditions of the Creative Commons Attribution (CC BY) license (http://creativecommons.org/licenses/by/4.0/). 